\title{
DISCUSSION
}

\section{Is There a Continuity in Modern German History? If Yes, How Many?}

\author{
Siegfried Weichlein
}

\begin{abstract}
William W. Hagen, German History in Modern Times: Four Lives of the Nation. Cambridge: Cambridge University Press. 2012. 482 pp. f19.99 (paperback).
\end{abstract}

How are we to conceive of modern German history? For decades historians have addressed this question through the 'vanishing point' (Helmut Walser Smith) of twentieth-century dictatorship, particularly the Nazi dictatorship and the Holocaust. Explicitly or implicitly, this approach has provided the most powerful master narrative in the historiography of modern Germany. It has had both advantages and disadvantages. It has made a coherent narrative of German history possible and allowed for the integration of political, cultural and economic data into an overall explanatory framework. It has been flexible enough to give room to quite different representations. ${ }^{1}$ The flipside has been that, epistemologically, it ran contrary to historical understanding and hermeneutics. It has held that a latter event was able to provide the reason for a former event, whereas ontologically the former always explains the latter. The focus on the Third Reich and the Holocaust could thus be read in one of two ways: either as an epistemological lens, through which certain earlier events became more important than others, or-particularly within emotionally charged debates - as a result and consequence of modern German history, especially the long nineteenth century. Particularly in the Anglo-American historiographical community, critical observations were made early on. David Blackbourn and Geoff Eley replaced the idea of 'German exceptionalism' with 'the peculiarities of German history'. ${ }^{2}$ German Alltagsgeschichte pointed to the 'Eigensinn' of historical actors rejecting the attempt to subsume different realities under one coherent and cogent master narrative. ${ }^{3}$

William W. Hagen, modern European historian at the University of California, Davis, has now published a book on modern German history from the Reformation to Unification, spanning a total of around 500 years. He does not tell one story, but four: the four lives of the German nation. He distances himself from every kind of 'German exceptionalism' or long-term structural Sonderweg. He does not employ developmental models of any sort to integrate German history from 1500 to 2000. Instead

\footnotetext{
${ }^{1}$ Cf. Hans-Ulrich Wehler, Das Deutsche Kaiserreich 1871-1918 (6th edn, Göttingen, 1988); Helmut W. Smith, The Continuities of German History: Nation, Religion, and Race Across the Long Nineteenth Century (Cambridge, 2008); Heinrich A. Winkler, Der lange Weg nach Westen, 2 vols. (Munich, 2000-2001).

${ }^{2} \mathrm{Cf}$. Geoff Eley and David Blackbourn, The Peculiarities of German History: Bourgeois Society and Politics in Nineteenth-Century Germany (Oxford, 1984).

${ }^{3}$ Cf. Alf Lüdtke, Alltagsgeschichte: Zur Rekonstruktion historischer Erfahrungen und Lebensweisen (Frankfurt/Main, 1995).
} 
he distinguishes between 'a succession of polycentric national existences' (p. 17). In his introduction he makes clear that the book's subtitle, 'Four Lives of the Nation', does not point to the historical continuity of an organic whole, 'but rather to four quite different epochs in the experience of the German-speaking peoples of central Europe'. He acknowledges continuities but is much more interested in 'ruptures so great as to occasion the disappearance of social, political, and cultural identities and the death of worldviews and spirits of the age' (p. 2).

What does he mean by 'four lives of the nation'? First of all he refers to the impact of the political system on its citizens: the first life is the era of the pre-nationalist German lands, the second that of the long nineteenth century, the third is the interwar period and the fourth and final life is the postwar era since 1945. His somehow shaky terminology of 'lives of the German nation' refers to a relative constancy of experiences and the political environment, constituted by both commonalities and contentions. Politics is the driving element in this book, which gives an overall synthesis to socio-political history. It is not the political system itself that he aims to explain, but rather its impact on the everyday life of Germans. Hagen does not imply four German nations, nor does he refer to one nation in four guises. These 'national lives' were not strictly autonomous but interacted with the lives of their European neighbours and the United States. The author organizes modern German history in the form of a textbook, constantly providing background information on important personalities, events and institutions. A vast number of maps, tables and figures illustrate the text. But this is not an exercise in political iconography, since the figures do not have a language of their own in the book.

How does Hagen explain the internal cohesion of these four lives, and how does he tackle the troublesome question of how to pass from one life to the next? How do the chosen caesuras organize German history and, most importantly, is such an organization of modern German history convincing? Geographically, Hagen turns to German-speaking central Europe, including the lands of the Habsburg Empire. He analyses the political institutions of the Holy Roman Empire and concludes that the Old Reich did not qualify as a modern state. ${ }^{4}$ Over time, the Old Empire proved unable to develop any lasting structures of statehood. The prevalent mentality in the first German life, before the French Revolution, was characterized by confessional divide, federalism and the tradition of enlightened reform politics in the German states. This political mentality came to an end with the challenge of the French Revolution, which called for a new, decidedly national response. This response came to be the common characteristic of the second German life in the long nineteenth century, until the First World War. In this respect, Hagen includes Austria and goes beyond a kleindeutsch-, Prussian-centred view. The German life world of the nineteenth century is sketched out as a bourgeois world with liberal values. Ethnic nationalism grew in the German Empire of 1871, but was particularly strong in the Habsburg Empire. Nationalism and liberalism went hand in hand at the beginning of the nineteenth century but were no longer synonymous at its end. Indeed, they had become antagonistic. Where nationalism could reach out to the lower classes, liberalism could not. The German Empire,

\footnotetext{
${ }^{4}$ Contrary to Georg Schmidt, Geschichte des Alten Reiches: Staat und Nation in der Frühen Neuzeit 1495-1806 (Munich, 1999), who argues that the Old Reich indeed showed characteristics of a state.
} 
which liberals had longed for over decades, was decidedly illiberal, albeit based on a democratic franchise which, however, favoured socialists and Catholics rather than liberals.

The author points out the inherent contradictions of modern German history particularly in the late nineteenth and early twentieth centuries, their impact on the lifeworlds of the citizens of the German states, and the consequent restrictions and challenges. One of the most advanced representations of political modernity was the constitution of the Weimar Republic in 1919. In Weimar the antagonisms of modern German history were played out in the open: political radicalization under the auspices of modern mass culture and mass politics, high modernity in roaring speed alongside racial utopias. Astonishingly, the author does not include a couple of telling antagonisms within the liberal bourgeoisie: first, its long tradition of anti-Semitism, and second, its deeply entrenched opposition to parliamentary rule despite its emphasis on the 'rule of law'.

The Third Reich was just one of several possible outcomes of German history. 'It resulted from collusion in the NSDAP's 1933 "seizure of power" of conservative elites - both aristocratic and bourgeois - that had never reconciled themselves to Weimar democracy, and from divisions among National Socialism opponents' (p. 283). In the same way the Holocaust was not the consequence of modern German history. At the end of his remarkable chapter on Jewish life in Germany the author concludes: 'In 1914 the arrival of anything remotely like severe anti-Semitic violence was unimaginable' (p. 224). To understand the origins of the murder of the European Jews requires a look at the Second World War and particularly the establishment of an Aryan Lebensraum in Eastern Europe. In addition to the long history of anti-Semitism it was the appeal of a pure racial community, which, under the stress of a consciously triggered war of extermination, set in motion a chain of events that treated defenceless and helpless people as atrocious war enemies. For this the Nazis found compliance in German society.

The fourth life of the German nation began 1945 and centred around a democratic West Germany. Treating postwar Germany as a fourth life raises the question of the 'Zero Hour'. There has never been a 'Zero Hour', for many Nazis and their collaborators held important positions in West German society up until the 1960s, sometimes even longer. The refounding of the German Society according to liberal and democratic values took decades and a new generation. Hagen is aware of this problem. The reason for the democratic turn of German society lay in the politics of the Western powers after 1945. It was their influence that overcame the antidemocratic resentments in German society.

This textbook raises fundamental questions about the periodization and the coherence of modern German history: a history that narrates a chain of events in an understandable and causal way relies on interpretation. Interpretations tend to overhomogenize their historical subjects. How can an author be coherent without being teleological? These questions become particularly important when it comes to Nazi dictatorship and the Holocaust. The question 'Who did it?' looms large over every account of modern German history. How can one live up to the moral questions of modern Germany while at the same time letting the sources and actors have their say, when they run contrary to our answers? 


\section{Continuity and Change}

In order to give an interpretative account and include dissent, the notion of development, so familiar to German historiography since the heydays of historical scholarship in the nineteenth century, has been prominent. Development spans decades and centuries, it evolves and unfolds, from time to time it realizes itself or even 'rises to its height'. The notion of development is close to organic language. How can a historical narrative explain change over time and at the same time avoid reifying organic language? Furthermore, the central variable for development has long been structures. Structures allow the narration of continuity and change. Although an analytical concept, structures tend to get reified and then to act like individuals. Once reified they convey a sense of continuity that cannot be falsified through the sources.

The author avoids the traps of reifying organic language. Whereas the structuralist accounts wrote about nationalism, liberalism and conservatism, we find in this book individual liberals, such as Jacob Venedey, and nationalists. Hagen underlines his actor-centred approach with many pictures and biographies of his protagonists. But then, what made Venedey or Theodor Mommsen liberals, and Adolf Stöcker an anti-Semite? In most of these cases the author argues with actions: Venedey was a 1848 revolutionary and Mommsen resisted Heinrich von Treitschke in 1879, Stöcker launched the anti-Semitic Christian social movement. Although he thereby adheres to his methodology, this causal circle is unsatisfactory.

Continuity belonged to the methodological toolbox of national historiography, since it implies notions of overarching identity through time. And this was particularly interesting for national historiography. When that tradition lost its attraction, historians began to replace concepts of national continuity. That has been done quite extensively in cultural history and in the cultural history of nationalism. ${ }^{5}$ Concepts such as 'invention of tradition' by Eric Hobsbawm and 'imagined communities' by Benedict Anderson were instrumental in deconstructing national continuities.

The deconstruction of national continuities has, however, not been the end of the story. Even when historians argue for constant change, this is theoretically only possible if change is measured against the backdrop of continuity. 'That something is undergoing change can only be understood relative to that which does not change'. If everything changes, change cannot be measured. Change is a discontinuity within a context of the non-changing. It is never total or complete disruption. It requires something related to the entity undergoing change that does not change. In this sense continuities make change possible. Continuity and change imply each other. They share a 'mutually constituted nature'. ${ }^{6}$ Colin Wight warns us to be wary of grand claims that there is change everywhere and at any time, since there are always elements of continuity within change. Also, change is not simply related to actors deciding for change. 'Agents bring about change, but not in circumstances of their own choosing; the sources of change can reside in the agential or structural conditions'. We have not really understood the

\footnotetext{
${ }^{5} \mathrm{Cf}$. Siegfried Weichlein, ,Nationalismus und Nationalstaat in Deutschland und Europa: Ein Forschungsüberblick', Neue Politische Literatur, 51 (2006), pp. 265-351.

${ }^{6}$ Cf. Colin Wight, 'The Continuity of Change, or a Change in Continuity?', International Studies Review, 3 (2001), pp. 81-9, here p. 82.
} 
relationship between change and continuity in theoretical terms. So far change has been aligned with sharp breaks, ruptures or revolutions. But there are other and slower modes of change. Change itself can be continuous. This change can be a mode of continuity, and so the question arises as to whether there are different modes of continuity or, conversely, whether continuities can change.

In the book we get a picture of many contradictions constantly resurfacing and creating antagonisms within politics and culture. This might have been a good path to pursue, but we are never given any form of comprehensive or synthetic accounts of the grammar of conflicts: political conflicts, economic conflicts, cultural conflicts, religious conflicts, ethnic conflicts. The challenge for historians who abandon any kind of master narrative - and rightly so! - is at least to come up with some kind of conflict theory, if only implicit. What kind of conflicts are embedded in the matter that is about to be narrated? Which conflicts are conflicts of a higher level, or meta-conflicts, so to speak, producing other conflicts? What kind of conflicts are more important: those about race or those about class, those about culture or those about party alliance?

The economic historian Alexander Gerschenkron has tried to theorize and conceptualize continuity and change. He distinguished between five different forms of continuities: constancy of direction, periodicity of events, endogenous change, length of causal regress and stability of the rate of change. ${ }^{7}$ Each of these forms provide a matrix for the study of continuity. They are interlocked and cannot be neatly separated. For instance the constancy of direction refers to the origins of processes of growth and expansion. It allows for change within the same direction, for speeding up and slowing down. Only the direction accounts for continuity, not the speed or the identical direction. Seen from this perspective, even setbacks can be integrated within continuity. Continuity as constancy of direction is different from continuity conceived as periodicity. When periodicities are interrupted this may not affect the constancy of direction. 'What makes continuity at periodic density a worthwhile tool of historical analysis is manageable length of the periods and also the fact that periodicity requires abstraction and generalization: a certain complex of phenomena must be paired out from the mass of kindred historical tissue'. ${ }^{8}$ The historical circle from democracy, aristocracy and monarchy depends on change. Change can have the form of continuity, if one accepts the Aristotelian view of the political circles. Changes from tyranny to aristocracy or from oligarchy to democracy, are then part of that continuity. Even revolutions and panics can be part of that continuity, if they are seen as mechanisms for recurrence. Continuity can be conceptualized by repetition. In sum, Gerschenkron argues for the compatibility of continuity and change through flexible criteria of continuity.

Peter Burke moves in the same direction. ${ }^{9}$ He quotes Fernand Braudel, the historian of the longue durée and the Mediterranean, who was critical of the history of events, the histoire evénémentielle. For Braudel these events were merely 'surface disturbances', 'crests of foam that the tides of history carry on their strong backs'. He and his followers in

\footnotetext{
${ }^{7}$ Alexander Gerschenkron, 'On the Concept of Continuity in History', Proceedings of the American Philosophical Society, 106 (1962), pp. 195-209.

${ }^{8}$ Gerschenkron, 'On the Concept of Continuity in History', p. 202.

${ }^{9}$ Peter Burke, 'Introduction: Concepts of Continuity and Change in History', in Burke (ed.), The New Cambridge Modern History, vol. 13: Companion Volume (Cambridge, 1979), pp. 1-14.
} 
the Annales School favoured concepts of continuity that were flexible enough to incorporate changes at the level of the history of events. What the history of mentalities was for Braudel, rationalization was for Max Weber. Marxists of different kind held steadfast to a conception of history according to which change was instrumental for continuity - the continuity of class warfare. Contrary to Marxism and Max Weber, the French Annales School did not privilege overarching concepts of continuity spanning centuries or even world history. Whereas revolutions were of quintessential importance for Marxism as well as for modernization theory, Braudel's interest lay more in past continuities: why did the French old regime persist for so long?

For other historians - including the adherents of modernization theory - the concept of tradition played a major role in analysing past continuities of old regimes. Tradition turned from an argument in the sources into an analytical concept. It had been a self-explanatory concept. Historians began to understand that tradition involved a complicated and multi-level set of practices. Tradition meant enormous labour, coordinated practices and an in-depth understanding of the social, cultural and economic implications of continuity.

William W. Hagen also observes continuities, but he sees them in a different way. He places them mostly beyond German borders. When he praises the Weimar constitution of August 1919 as the most modern constitution, he does this comparatively with regard to the French or American constitutions. After 1945, when describing postwar democracy, he puts the influence of the Western occupation powers centre stage. In the same vein, he underlines the influence of the reformist Soviet Union under Gorbachev and the other protest movements in Eastern Europe for the downfall of the Berlin Wall in 1989. The continuities in this book are in fact similarities between standards of political life in West and East Germany respectively. It was not tradition, nor the growing force of a democratic party, nor the protesters of 1989 that moved German society into a democratic era, but rather the changing constraints of Germany's neighbours in the West as well as in the East. The author is right to distance himself from any sort of master narrative. But you cannot escape the thorny questions of self-perpetuating inequalities within German society.

William Hagen identifies four historical life worlds. How did they learn from each other? How did they position themselves in relationship to their predecessors? Where are processes of learning and forgetting, of adaptation and rejection? How did the second German life after the French Revolution learn from the first German life before 1789? Asking for learning processes does not imply that learning in an absolute sense indeed took place. But it takes seriously the inherent claim of the historical actors, not to act as if they were the first, but to continue, defend, rebuild and expand on what they experienced as their past.

University of Fribourg siegfried.weichlein@unifr.ch 